DOI: 10.2478 /ausp-2020-0028

\title{
Hungarian Dialectology. From the Beginnings until the Division of Hungary (1920)
}

\author{
Csaba Attila BOTH \\ Doctoral School of Hungarology Studies \\ Babeş-Bolyai University, Faculty of Letters \\ bothcsabaattila@gmail.com
}

\begin{abstract}
Dialect islands in Hungarian dialectology have been a marginalized segment of research. Although the very first observations on different Hungarian dialects appeared in the $17^{\text {th }}$ century, a systematic and detailed monographic description of Hungarian dialect islands in the Carpathian Basin has not been published yet. As we can conclude, several important historical events happened, institutions and researchers emerged. All of them had a significant impact on this research area, and based on their emergence the research history of Hungarian dialect islands can be divided into different periods. With regard to the research history of Hungarian dialect islands in Romania, a research was conducted in 2019. The results showed that the research history of these islands cannot be understood without an adequate global image of the history of the Hungarian dialectology. Thus, the present article gives a general historical overview of the research on Hungarian dialects from the beginnings up until 1920, when, following the Treaty of Trianon, the Hungarian nation was divided into five different parts.
\end{abstract}

Keywords: Hungarian dialectology, dialect island, research history, Transylvanian dialectology

\section{Introduction}

The activities (fieldwork, research, publishing) belonging to the field of dialectology fall into two major groups. One group consists of works and studies that focus on the linguistic material and thus on the use of the language itself as well as on the linguistic system. Dialectology (mainly before the appearance of the geolinguistic method but following its appearance as well) comprises such research: registers of linguistic data of the folk language, shorter publications about interesting dialectological features, and possibly small monographs on dialects. The common point of the works of the second group is the fact that the linguistic data themselves become tools in order to achieve the goal of the research. Here we refer to situations 
where the linguistic material is a tool which helps to answer basic questions of the research - for example, research on dialect typology, isoglosses, or, more recently, dialectometric methods, which also pertain to this group, and so does research on dialect islands as it is, in fact, typological research. It is precisely the character of the dialect island that differs to a greater extent in one or more typological features from the dialect of the larger area in which it is embedded.

The research behind the present article had its focus only on the Hungarian dialect islands in Romania, but we cannot pretend that they have only been investigated since they became "Romanian". The Trianon Treaty put an end to the First World War a hundred years ago, and, as a result, the Hungarian language area and nation (with all of its institutional systems) was divided. Nevertheless, on the one hand, the roots of scientific research are common since the beginnings date back to earlier than the 1920s, and, on the other hand, the main directions of research in this field have still been determined by science schools in Hungary, both theoretically and methodologically, allowing appropriate freedom and openness to research centres and universities that are now reaching across.

Therefore, in the light of the above-stated facts, I do consider it relevant for the topic to look at the history of dialect research concerning the Hungarian beginnings.

The more elaborated methodological roots of such research in Hungarian linguistics are likely to be looked for in German linguistics, ${ }^{1}$ but the influence of the French language atlas was also extremely significant. In the age of Humanism and Reformation, questions of origin came to the fore. It was in this era that Transylvanian Saxons also became the focus of German intellectuals.

It is also important to note that there was a geopolitical reason for the increased interest in dialects (especially in geolinguistic atlases). By the beginning of the $20^{\text {th }}$ century, the ideology of nationalism had slowly ripened only to culminate in conflict (World War I). And the nation is the people, the people who use a certain language. It is no wonder then that the contemporary powers considered it worthwhile supporting the works of geolinguistics; thus, they could also provide tools for the argumentation of their own ideology (i.e. the forerunner of the nation, its geographical extent).

\section{Periods of research on the Hungarian eastern dialects}

As far as Hungarian dialectology is concerned, no work has yet been published that provides a detailed and systematic overview of the history of this discipline. However, several articles ${ }^{2}$ were published in the past that referred to the necessity of research

$1 \quad$ See Nagy 1984.

2 See Erdélyi 1904, 1905a, 1905b; Bárczi 1955; Márton 1973; Imre 1971, 1978; Szabó J. 1990 : 13-25; Szabó Z. 1993; Bakó 1994; Cs. Nagy 2007. 
on Hungarian dialects. Therefore, it is but natural that the starting point of these texts is an overview of the major dialectological works that had been completed by that time, usually ending in highlighting deficiencies. Moreover, the authors pointed out the urgent need to fill in these deficiencies and outlined new directions for research. In Hungarian dialectological literature, there is no publication dealing with the historical aspects of the discipline without highlighting the facts that Hungarian dialect research is generally lagging behind European trends and that Hungarian researchers are still struggling to answer those questions for Hungarian dialects for which German, French, English, American, etc. dialectology has long responded.

I do not intend to carry out this kind of systematic review of the history of research in my article. However, in order to be able to have an appropriate overview of the history of research on Hungarian dialect islands in Romania - which is part of the dialect research, not a separate discipline -, it is necessary to embed it in the history of dialectological research. As it does not refer to Hungarian dialects comprehensively but only to the ones spoken on politically and administratively marked areas on the current territory of Romania, which at the same time are largely distinct geographically, historical references are essential.

At this point, there may be a concern regarding division in periods, and it refers to the aspects of the period that is the basis on which the researcher decides where to draw the boundary between two periods. Depending on the nature of their subject, the various periods can be very accurate but also arbitrary. For example, in the history of the Hungarian language, Jenő Kiss describes the period limited to historical events with the most important consequences for linguistic changes (Kiss 2018: 43-44). The periodization in this research is based on the divisions marked by predecessors and may coincide with them at some points. The basis of this periodization relies mainly on important micro-historical events, important personalities, and significant paradigm or methodological changes.

\subsection{The beginnings of popular language research (1645-1872)}

We can name the first major period of Hungarian dialect research the beginnings of popular language research. In our interpretation, this period dates from the year 1645, when István Geleji Katona published his Magyar Gramatikatska towards the end of the age of language reform, when the Magyar Nyelvốr journal appeared in 1872.

Samu Imre affirmed: "what happened in our country was almost a literal recurrence of what had happened abroad". ${ }^{3}$ We can agree with him since the beginnings of Hungarian dialect research covering almost 230 years are very similar to those of German collections of dialectological peculiarities. It were the authors

3 „Ami nálunk történt, az szinte szó szerinti ismétlődése volt a külföldön történteknek” (Imre 1971: 7). All Hungarian citations were translated by the author. The original Hungarian texts are presented in their original orthographic rules. 
of the texts describing the Hungarian nation and language that first dealt with the linguistic features of certain Hungarian ethnic groups (especially the Székelys, ${ }^{4}$ who had already been perceptualized as some kind of linguistic island and whose dialect was different to a greater extent from the other Hungarian dialects). Works from a later period might be considered to be dialectological as they comprise collections of idioms and later on the description of dialects as well.

This period can be divided into two smaller periods: we can name the first one as observations regarding folk language before the language reform whereas the second one as research of folk language during the language reform. I consider that the Marczibányi reward issue ${ }^{5}$ organized by the Magyar Nemzeti Múzeum ${ }^{6}$ in 1818 marked the boundary line between them. The importance of this event lies in the fact that it made possible for the thinkers of the period to confer and have regular discussions about the existence and nature of Hungarian dialects and their typological description.

\subsubsection{Observations regarding popular language before the language reform (1645-1818)}

According to Lajos Erdélyi, it should not be surprising that our scholars were interested in our dialects in the past even though they showed real interest in dialects only when they turned towards the popular culture, that is, at the beginning of the $19^{\text {th }}$ century. ${ }^{7}$

István Geleji Katona was one of the earliest of these scholars. In his Magyar Grammatikatska (1645), he commented on the different ways of how vowels were pronounced in certain dialects. He specifically mentioned the Székelys, and he stated that the Székelys were genuine descendants of the old Scythian Hungarians (Geleji Katona 1645: 32). In his writings about the Székelys, István Szamosközy, Transylvanian humanist of the $20^{\text {th }}$ century, made several comments on their language and pronunciation. Similarly, Antal Maginus drew attention to the diversity of the Székelys in his Geographia. In his work Hungaria, Miklós Oláh names the Székelys, Cumans, ${ }^{8}$ and Jazis ${ }^{9}$ as nations different from the Hungarians. Dávid Baróti Szabó's writings, namely Kisded Szótár and Magyarság virago, contained many words of Transylvanian and Székely origin (Erdélyi 1905a: 292-294).

$4 \quad$ Known also as Seklers or Szeklers.

5 We could interpret the Marczibányi reward issue (Marczibányi jutalomkérdések) as a research grant. It was organized by the Hungarian National Museum in order to ask the thinkers of the era to present their views on the status of Hungarian dialects.

6 Hungarian National Museum.

7 „Nem csodálhatjuk, ha nyelvjárásaink iránt már a régibb múltban is érdeklődtek tudósaink s mások is, noha az igazi érdeklődés csak azóta fordult feléjük is, a mióta a nép felé, t. i. a XIX. század eleje óta" (Erdélyi 1905a: 292).

8 Kunok.

9 Jászok. 
We should also mention the Erdélyi Magyar Nyelvmívelö Társaság ${ }^{10}$ founded by György Aranka in 1791, who was Ferenc Kazinczy's ${ }^{11}$ correspondent during the language reform. Thus, it is not surprising that during the Enlightenment the Társaság, with its popular language research, took part in the language reform. ${ }^{12}$

\subsubsection{Research of popular language in the age of language reform (1818-1872)}

In Erdélyi's view, a more conscious turn to the language of the people was brought about by the age of language reform, when scholars focused on how the Hungarian language could be enriched. József Kassai noted that "S. (Scientist) Mr József Márton, who published a German and a Hungarian-German Dictionary in Vienna in 1807, started to record which words had Transylvanian or Székely origins and which were Hungarian words, more precisely, which word was used in the area where the Tisza or the Danube Rivers flow" ${ }^{13}$ Between 1799 and 1800, Kassai also completed a collection of popular languages to expand the corpus of his dictionary. References to local idioms (some of them spoken by Székelys, others occurring in Szeged, Vas, and Somogy counties as well as in Bodrogköz) were also published in the Tudományos Gyújtemény journal. Reflections are made on the pronunciation encountered in certain regions (Erdélyi 1905a: 295).

King Francis I of Hungary had the second Ratio Educationis published on 4 November 1806, which gave greater prominence to the teaching of the Hungarian language and history. Thus, this law "has relit the fire in our Hungarians, and, beyond private scholars and language-cultivating societies, even counties have united in order to fill in deficiencies". ${ }^{14}$

In response to this law and the ever-expanding need for the Hungarian language to gain space, between 1815 and 1817, the Magyar Nemzeti Múzeum formulated four groups of questions about the Hungarian language (Marczibányi reward issue): 1. What is dialect in grammatical terms? Do dialects exist in the Hungarian language: If so, which are they? How are they different? How can they enrich the Hungarian language? 2. What scientific rules should be used to enrich the Hungarian language with new words and phrases? 3 . What would be the best way to create a perfect

10 Transylvanian Society for the Cultivation of the Hungarian Language.

11 Ferenc Kazinczy: leading figure of the Hungarian language reform.

12 For more on the activity of György Aranka and the Erdélyi Magyar Nyelvmívelö Társaság, see: Benkő 1994.

13 “T. (Tudós) Márton József úr, a ki német és magyar-német Szókönyvet bocsátott közre Bétsben 1807-dikbenn, kezdé Szókönyvében imitt-amott feljegyezni, meljik légyen Erdélyi, vagy Székely szó; meljik magyarországi, úgy mint a Tisza melléki vagy Duna melléki szó” (Kassai Magyardiák Szókönyve I. csomó, qtd. by Erdélyi 1905a: 295).

14 „[...] ujj tüzet adott Magyarainkba, és már most a’ meg lehető fogyatkozások pótlásokra, még a' Vármegyék is egyesítették magokat egymással, a' magánok Tudósokon és nyelvmivelő Társaságokon kívül” (Gáti 1821: 5). 
Hungarian lexicon? Should it cover the archaic elements of the Hungarian language and its provincial words and phrases or the Hungarian dialects? Which is the shortest and the most appropriate way to achieve all this? 4. How could Hungarian spelling be based on philosophical principles rather than opposing habits and arbitrary opinions? (Gáti 1821: 5-6).

The answers to these questions were published in several volumes by István Horváth in 1821. Published in 1815, the first volume comprises Ádám Palóczi Horváth's work entitled A'Magyar Nyelv' Dialectusairól. It presents the reader with his views on Hungarian dialects expressed in question-answer form. Based on Greek traditions, Palóczi paralleled the research and possible grouping of Hungarian folk language with the interpretation and system of Greek dialectology. Against this background, we now see the methodological viewpoint according to which writing and pronunciation, as well as "origin", are the most important issues.

The author identified two major varieties of Hungarian dialects and their smaller territorial variants. In his opinion, one of the main variants had harsher sounding (Danube), whereas the other variant sounded more softly (Tisza). The boundaries were located between the Danube and the Tisza rivers, and he also noticed the fact that they were not sharply separated but overlapping. He identified the two main dialects on the basis of such phenomena as the pronunciation of the $l[1]$ consonant or the pronunciation of $\ddot{o}[\varnothing]$ (which is pronounced like a certain $e[\varepsilon]$ ). The following subtypes of the Tisza dialect were defined as being spoken in smaller areas: in Trans-Tisza, Hegyalja, Pataki, and Tótos counties; the subdivisions of the Danubian dialect occur in counties closer to the Danube: the region of Somogy, Baranya, Ormánság with Okor region, most of Vas and Zala counties, especially the region of Götsej and Kerka, further on, the region of Palócs and the region of Gyöngyös (Palóczi Horváth 1821: 56).

At the same time, Palóczi drew attention to a desirable attitude that appears only in the modern sociolinguistics, and it refers to the equivalence of dialects (Palóczi Horváth 1821: 74).

In the second volume, István Gáti’s work entitled Elmélkedés a' magyar dialectusról, lexiconról, és helyes írásról was published. For us, the most important part of this work is the attempt to complete a typological classification of dialects. Gáti's classification differed somewhat from that of Palóczi. He claimed that there were two main dialects, one for the literate 'írástudók' and one for the illiterate 'írástudatlanok'. Furthermore, he distinguished two subtypes of the main dialect of the literate: the one spoken in the Tiszta region and the other one which was spoken in the Duna district. This is most often the language of the Catholics, while the other one is that of the Protestants. ${ }^{15}$

15 „Tisza-mellyéki és Duna mellyéki. Ezt többnyire a' Catholicusok, Amazt a’ Protestánsok követik” (Gáti 1821:15). 
As for the other main dialect type, the one for the illiterate, Gáti said that the number of dialects spoken by common people in the Hungarian homeland is nearly as large as the number of the counties. ${ }^{16}$ Nevertheless, he highlighted four of them, which he considered most famous: 1) Highlander, or Danubian dialect; 2) the Great Plain, or the Tisza dialect; 3) the Görgói Balog Valley dialect in the Northern parts; and 4) the Székely dialect in Transylvania (Gáti 1821: 18).

István Gáti's classification is extremely interesting from a modern viewpoint since he took into account social factors that are beyond geographical classification and will be considered by the research of living language as decisive factors (education, religion) only much later.

The previously mentioned Marczibányi questions formulated by the Magyar Nemzeti Múzeum, but most of the works published in response to them (Horváth Palóczi, Gáti) as well as Fábián Szeder's work on the Palócs (1819), paved the way for the forthcoming collections of folk language (Erdélyi 1905a: 296).

In his work entitled Némely vélekedések a magyar nyelv ügyében, published in Szeged in 1825, József Nátly mentioned idioms occurring in the Tisza dialect. Two volumes of Ferencz Kresznerics’s book, Magyar szótár gyökrenddel és deákozattal, published in Buda between 1831 and 1832, and the work entitled Származtató és gyökerészố magyar-diák szókönyv by József Kassai, published in Pest between 1833 and 1835, contain a lot of interesting folklore data. As a result of the rise of Romanticism on the national level, as Károly Kisfaludy and his followers embraced the use of folk elements, they inspired and supported folk research. Tudományos Gyújtemény published the works of István Horváth as follows: $A$ jászokról, mint magyar nyelvú népról és nyilazókról (1829), A jász nemzet nyelvéról (1833), A székely nemzet nyelvéról (1834), and A palóc nemzet nyelvéról (1834). Moldavian Hungarians ${ }^{17}$ also appeared in the discourse in Elek P. Gegő's work A moldvai magyar telepekról (P. Gegô 1838), in which he accounted for his journey through Transylvania, with a thorough description of the local people. Magyar Tudományos Akadémia $^{18}$ and Kisfaludy Társaság ${ }^{19}$ were founded in the 1830s, and eight years later they published Magyar Tájszótár. In 1843, János Erdélyi was entrusted with collecting folk traditions (Erdélyi 1905a: 298). It was then that collecting folk traditions, poetry, songs, and ballads began to unfold; by then, János Kriza had already announced a subscription to support his collection Vadrózsák. It was published much later in Kolozsvár in 1863, with the support of Count Imre Mikó.

The issue of the origin of the Saxons, which was slowly unfolding in German linguistics at the time, made Hungarian researchers take a deeper interest in

16 „a' köznép dialectusa a’ magyar Hazában tsak nem annyi, mint a’ Vármegyék száma” (Gáti 1821: 18).

17 Also named Csángós.

18 Hungarian Academy of Sciences.

19 Kisfaludy Society. 
the origin of the Székelys (Szabó J. 1990: 17). Such an example is József Vass's work published in 1860, in which he seemed to describe the dialect spoken on Transdanubian areas, concluding that the language of the Székelys and that of the people of Göcsej must be similar due to their common roots (Vass 1860: 65).

In his work, he thoroughly examined all kinds of linguistic phenomena in the Transdanubian dialect, but comparisons with the Székely dialect were missing. Nevertheless, Vass's writing is one of the first Hungarian-related texts in the Hungarian language to support a certain issue based on linguistic data that would somewhat explain the origin of the population and would interpret the history of their settlement.

By the end of the 1850s, partly under the influence of foreign linguistics, Hungarian linguistics had begun to be institutionalized in the form of specialized journals. The publishing of Magyar Nyelvészet, edited by Pál Hunfalvy, began in 1856. The journal changed its name to Nyelvtudományi Közlemények in the 1860s, and it is being published with this new name. In the beginning of the 1870s, another journal, Magyar Nyelvór was released, which meant the opening of a new period in Hungarian dialect research (Erdélyi 1905a: 298-299).

\subsection{From the beginnings of Magyar Nyelvốr to the Treaty of Trianon (1872-1920)}

\subsubsection{From the beginnings of Magyar Nyelvôr until the foundation of Magyar Nyelvtudományi Társaság (1872-1904)}

It was the release of Magyar Nyelvór that marked the emergence of the institutionalized form of Hungarian dialect research. The journal provided a constant space for reflection on Hungarian dialects, the articles published in it received more publicity, and the so-called professional control also came into being as the articles received for publication were reviewed by the editorial staff and were at times criticized. According to Géza Bárczi, "what we know about our dialects today is due to the hard work of a collection of this era. The results were so rich that the second Magyar Tájszótár (József Szinnyei 1893-1901) as well as the first scholarly synthesis (József Balassa: A magyar nyelvjárások osztályozása, 1891) could be completed". ${ }^{20}$

However, Magyar Nyelvốr was not the only journal in which writings about folk language could be published. We will see that Ethnographia also played an

20, „...] amit ma nyelvjárásainkról tudunk, annak igen jelentôs részét e korszak szorgalmas gyújtőmunkájának köszönhetjük. Az eredmények oly gazdagra gyưltek, hogy a tudományos színvonalon álló második Magyar Tájszótár (Szinnyei József, 1893-1901), sôt az első igényes szintézis is (Balassa József, A magyar nyelvjárások osztályozása, 1891) létrejöhetett” (Bárczi 1955: 60) - highlighted in the original. 
important role in publishing works on Hungarian dialects, while more extensive writings continued to be published in Nyelvészeti Füzetek as well as on the pages of the Erdélyi Múzeum journal. This period of almost fifty years is also important because it was in this era that the elementary foundations of systematic and methodical research of Hungarian dialects were laid. The Hungarian nation lived on one political territory, and researchers had not yet encountered obstacles that influenced the institutional, personal, material, and ideological background of the research, which later on took place within the framework of minority relations. By the end of the period, Hungarian dialectology had also reached, although largely on a theoretical level, an important methodological milestone that had already been passed by the Germans, the French, and others for over half a century - namely, the idea of a Hungarian language atlas.

In Hungarian linguistics, the popular-national tendency began to be felt strongly, just as in other areas of Europe. In addition to the aforementioned Magyar Nyelvészet and Nyelvtudományi Közlemények, in January 1872, a linguistic journal entitled Magyar Nyelvốr was released by Gábor Szarvas. Several articles on dialect and folk heritage descriptions were published in it, which, from today's perspective, might be considered bulky and more or less lacking scientific accuracy, but in the context of the age they did not lag behind the European standard of that time. The great majority of József Balassa's works, János Steuer’s papers and maps presenting the Székely sound system, Antal Horger's writings on Székelyland and the Csángó population of Hétfalu, Károly Haag's papers on dialect mapping, which were published in translation and in which he called for a direct method instead of the indirect one used until then, were all published in Magyar Nyelvôr. ${ }^{21}$

There is also a need for the historical interpretation of dialects; in 1898, József Balassa discussed the emergence of Hungarian dialects in the ninth edition of Ethnographia, entitled A magyar nyelvjárások keletkezése. In these publications, Balassa listed the dialectal regions and provided plenty of historical data about population and settlement, thus attempting to convey an explanation of how dialects had reached their contemporary state (Balassa 1898a, 1898b, 1898c).

The aforementioned issue of the Székely origin kept on remaining in the focus. The first pages of the first year of Ethnographia presented an interesting debate between Géza Nagy (1890), László Réthy (1890), Károly Tagányi (1890), and József Balassa (1890). There is no space here for the content of the articles to debate in detail, but it should be noted that, although the authors tried to explain the origins of the Székelys in different ways, each of them had made some kind of reference to the language. This is an important confirmation of what has long been established in linguistics - namely that the study of dialects provides strong arguments for settlement and population history. In the same line, it is worth

21 For other important dialectological works published in Nyelvốr and other interfaces until 1905, see: Erdélyi 1905a: 300-301. 
mentioning Balassa's study, which, in its method and presentation, foreshadowed the appearance of a major paper published a year later, entitled $A$ magyar nyelvjárások osztályozása és jellemzése.

There is an extensive introduction to his work, largely reviewing all the linguistic and non-linguistic factors to consider when applying classification. It approaches the issue from a historical perspective as it sought to follow the history of the Conquest, ${ }^{22}$ settlement, resettlement, and migration of the Hungarians, constantly referring to the linguistic consequences of these events. Furthermore, Balassa overviewed the perspective of the emergence of new dialects. He states that a new dialect could be created through self-development, under the influence of a foreign language, and if new settlers took up the Hungarian language during the process of language shift (Balassa 1891: 1-8).

According to László Deme, Balassa developed Simonyi’s classification based on the phenomenon of closed $\ddot{e}[\mathrm{e}]$. However, it was a novelty that he viewed certain individual dialects as independent systems (Deme 1953: 18).

In his paper dating from 1891, Balassa drew attention to the existence of different languages and dialects:

The Hungarian-speaking area still lies in the centre of the country, while the frontiers are inhabited by foreigners, except for the south-eastern border of Transylvania. South of the Danube at the western border, Germans and Wends live only on narrow strips, and the entire area between the Danube and Drava is inhabited by Hungarians; In Transdanubia and in the south, there are some Wend islands and in the north some Slovak ones. Across the Drava River, there are Croatians, we can find only a few Hungarian-speaking villages that are scattered in the area, real Hungarian islands amongst the Croatian population. Lately, many Hungarians have been migrating again, they cross the Drava and settle in Croatian villages. ${ }^{23}$

The population of Pest County is Hungarian, only a few Slovak islands are scattered amongst them, and on the south-western border of Bács County, there is a smaller German community. [...] To the south of Maros, we find only scattered Hungarian islands, the majority of the population is Wallachian,

22 Hungarian Conquest of the Carpathian Basin.

23 „A magyar nyelvterület ma is az ország közepét foglalja el, míg a határszéleket - Erdély délkeleti határának kivételével - idegenek lakják. A Dunától délre a nyugati határszélen csak keskeny szalagon laknak németek és vendek, ezen kívül a Duna és Dráva közé esô egész területet magyarok lakják, s csak kevéssé szaggatják meg kisebb német területek, délen Baranya és Tolna megyében és északabbra Veszprém, Fehér megyékben és Pest megye dunántúli részében, ezen kívül délen még néhány vend, északon pedig néhány tót sziget. A Dráván túl a horvát lakosság, s csak elszórva találunk Horvátországban néhány teljesen magyar ajkú falut, valóságos magyar szigeteket a horvát népesség között. A legújabb időkben ismét sok magyar vándorol át a Dráván, s telepszik le a horvát falvakban” (Balassa 1891: 2). 
German, and Serbian. The Hungarian population of the Great Plain is only cut into here and there by Slovak communities, but in the north, Gomor, Abaúj, and Zemplén counties are confined by Slovaks and Saxons, whereas in Ung, Bereg, and Máramaros Ruthenians set boundaries. In the east by Arad, Bihar, and Szatmár counties, Valahians cut in the Hungarian mass. In Szatmár and Zilah counties, the Hungarian population appears as larger islands amongst Wallachians; we see the same thing in the western counties of Transylvania, and it is Székelyland where we can find a coherent Hungarian language area extending to the border of the country. There are very few Hungarianspeaking areas beyond the borders of Hungary; Hungarian emigrants rarely preserve their language unless they emigrate in masses. Such Hungarian emigrants, called Csángós, are found in Moldova along the river Szeret and in some villages on the eastern border of Bukovina. ${ }^{24}$

Following Balassa's writings, József Pápay, in his shorter publication, showed that Kocs is a dialect: "In the Upper Transdanubian dialect, I think this is a unique place, an island indeed. Its language clearly indicates the nationality of the inhabitants. The way they pronounce the sound $\ddot{O}[\varnothing]$ proves that they have broken out of the Great Plain and migrated from there to their present place of residence". ${ }^{25}$

"Examining the dialectal features of this settlement, we are certain to say that the settlers were Hungarians from the Great Plains. [...] It is almost certain that the majority of the population of this place settled here from Kiskunság”. ${ }^{26}$

As our topic requires it, we need to mention some works from the early $1900 \mathrm{~s}$ that are directly related to the research history of dialect islands. Such an example is Sándor Nagy's work on the folk language spoken in Vác, published in 1903, as the author provided historical details of the settlement and of the settlers, whose original

24 „Pest megye lakossága magyar, csak néhány tót sziget tarkázza, és délnyugaton Bács megye határán van egy kisebb német vidék. [...] A Marostól délre csak elszórva találunk magyar helyeket, a lakosság nagy része oláh, német és szerb. Az alföldi magyarságot csak itt-ott szakítja meg egy-egy tót sziget, de határt szabnak neki északon Gömör, Abaúj és Zemplén megyékben a tótok és a szepesi szászok, Ung, Bereg és Máramaros megyékben pedig a ruthén lakosság, míg keleten Arad, Bihar és Szatmár megyékben az oláh terület szakítja meg. Szatmár és Szilágy megyékben nagyobb szigetekként tûnik fel a magyar lakosság az oláh lakosság között; ugyanezt látjuk Erdély nyugati megyéiben is, s csak az oláhságon túl, a székely földön találunk ismét összefüggő magyar nyelvterületre, mely az ország határáig terjed. Magyarország határain túl nagyon kevés a magyar nyelvú terület; a kivándorolt magyarok ritkán őrzik meg nyelvüket, kivéve ha egyszerre nagy tömegben vándorolnak ki. Ilyen kivándorolt magyarokat, úgynevezett csángókat, találunk Moldvában a Szeret folyó mentén, továbbá Bukovina keleti határán néhány faluban” (Balassa 1891: 3).

25 „A felső dunántúli nyelvjárásban úgy hiszem, egyedül áll ez a helység, valóságos sziget. Nyelve világosan rámutat a lakosok hovatartozóságára. Az ö-zése azt bizonyítja, hogy az Alföldről szakadt ki, onnan vándorolt mostani lakóhelyére” (Pápay 1896: 209).

26 "E helység nyelvjárási sajátságainak vizsgálata nyomán egész biztonsággal kimondhatjuk, hogy a betelepülők alföldi magyarok voltak. [...] Majdnem teljesen kétségtelen, hogy e helység lakosságának túlnyomó része a Kiskunságról telepedett ide” (Pápay 1896: 210). 
residence he also identified. He did not discuss dialect in this context; nevertheless, the relationship between settlement history and dialect is an outstandingly important aspect of dialect research. Similarly, it is worth highlighting Aladár Szemkő's work: based on the pronunciation of the $\ddot{o}[\varnothing]$ sound, he established that the dialect of Abaúj had an island feature. While observing the dialect spoken on the areas along the FeketeKörös (Jánosfalva and its surroundings), Géza Böszörményi concluded that linguistic facts proved the theory that the inhabitants of the community were of Székely origin, which is also the community's position about its members (Szabó J. 1990: 19).

Another significant achievement of the era was that József Szinnyei published Magyar Tájszótár between 1892 and 1901 using the language material collected by the end of the $19^{\text {th }}$ century and the material of the modest first Magyar Tájszótár published in 1838 (Bárczi 1955: 63).

\subsubsection{The age of decline (1904-1920)}

In 1904, Hungarian linguists founded Magyar Nyelvtudományi Társaság, ${ }^{27}$ and in the care of the newly formed Society another major journal of linguistics - Magyar Nyelv - was launched. In the first year of this volume (issues 7 and 8), Lajos Erdélyi published his two-part article on the past and the future of dialectology, entitled Nyelvjárásaink ügye és teendôink. Overviewing dialect research so far, he discussed Balassa's typology of dialects established in 1891, which identified eight dialectal regions and pointed out the importance of becoming familiar with dialects as well as listed all settlements that were relevant in this respect (see Erdelyi 1905b: 346-349).

At the turn of the $20^{\text {th }}$ century, Hungarian dialect research stalled until it stopped completely after the First World War. According to Samu Imre, this phenomenon is closely related to the fact that at that point there was still a certain harmony between historical and descriptive research. At the beginning of the 1900s, however, the new journal, Magyar Nyelv, was released, and thus Magyar Nyelvór lost its importance and became second-rate from the point of view of dialect research. The community of dedicated dialectologists was ageing by then, and, although the Magyar Nyelvtudományi Társaság still admitted the importance of learning about folk language and dialects, there were no significant results. The quality and the volume of Hungarian works published in Magyar Nyelv was decreasing as well. By the 1910s, dialectology-related publications had almost disappeared from the journal. Finally, on 19 November 1913, the Society's Board of Directors decided not to publish lists of words and expressions of the popular language that had been sent in. There were certainly financial reasons for this, but perhaps the most important aspect was that by then the historical approach had completely taken over in Hungarian linguistics (Imre 1971: 9). Zoltán Gombocz himself stated: "Undoubtedly, in recent decades,

27 Society of Hungarian Linguistics. 
our linguists have been interested only in the problems of Hungarian language history and Finno-Ugric comparative linguistics". ${ }^{28}$

According to Imre, the few works related to dialects published by rural universities were not better than the monographs of the early $20^{\text {th }}$ century, either in volume or in content (Imre 1971: 10).

In 1913, Károly Viski published his article $A$ szalontai nép nyelvéból in a special issue of Magyar Nyelvốr, which he called not a methodological study but rather a collection. He expressed his conviction that the dialect of Szalonta is not a dialect island, but the poet's ${ }^{29}$ childhood and youth make it an exceptional place. In this work, he emphasized certain dialectal features. At the same time, he stated that the dialect had properties that were roughly the same as those of the Tisza, more precisely the dialect variants with special phonological features (Viski 1913: 3-4).

Béla Vass published his monograph entitled $A$ nagykôrösi nyelvjárás in volume 57 of Nyelvészeti Füzetek, which revealed his highlight of the historical aspects of the settlement. Following its historical introduction, he stated that "the highly conservative Kőrös village absorbed and suppressed all sorts of dialects that could be assimilated under half of a lifespan to the local pronunciation. Thus, we can say that the dialect of Nagykőrös has not been subject to any foreign influence - except for the Turkish influence on the universality of our language and the transmissions of words". ${ }^{30}$

Samu Imre also pointed out that while Hungarian linguistics studying the spoken language had been almost completely disregarded by the scientific sphere, "language atlases are planned and compiled from Algeria to Estonia, from England to Romania [...], and, as it is known, they were the first to carry on collecting the material of the »Hungarian language atlases « since »Atlasul lingvistic român «, ${ }^{31}$ although small in number, also contains Hungarian data". ${ }^{32}$

In Géza Bárczi’s opinion, it was this period of nearly 25 years that Hungarian dialectology was gradually lagging behind European trends, and that could not be replaced by Bálint Csûry, Antal Horger, ${ }^{33}$ or Gyula Laziczius's works, irrespectively of their endeavour (Bárczi 1955: 60).

28 "Kétségtelen, hogy az utóbbi évtizedekben nyelvtudósaink érdeklődését kizárólag a magyar nyelvtörténet és a finnugor nyelvhasonlítás problémái kötötték le” (Gombocz 1927: 1).

29 He referred as poet to János Arany.

30, „[...] az erősen konzervatív szellemú Kőrös magába olvasztotta, elnyomta az összes besereglett nyelvjárásokat, amelyek egy fél emberöltő alatt assimilálódhattak az ottaniak kiejtéséhez. Így hát elmondhatjuk, hogy a nagykőrösi nyelvjárás nem szenvedett semmiféle idegen befolyást - leszámítva a töröknek nyelvünk egyetemlegességére gyakorolt hatását, szó átvételeit” (Vass 1909: 6).

31 Linguistic Atlas of the Romanian Language.

32, „...] nyelvatlaszok készülnek és nyelvatlasztervek születnek Algírtól Észtországig, Angliától Romániáig [...] ső́t - mint ismeretes - ebben az időben folytak már az első »magyar nyelvatlaszgyújtések « is, hiszen az »Atlasul lingvistic român «, bár csekély számban, de magyar adatokat is tartalmaz" (Imre 1971: 10).

He created the first Hungarian dialect map; see: Horger 1905. 
While the events mentioned above were unfolding in Hungarian dialect research, the First World War took place between 1914 and 1918, the consequences of which tore the Hungarian scientific life apart for a long time. On 4 June 1920, the Trianon Peace Treaty split up former Hungary, a country that used to be politically and administratively undivided, and fragmented its nation. Since then, we speak about Hungarians that live in Hungary and the ones living in Romania, Slovakia, and Austria as well as about Hungarian linguistics from these countries.

\section{Conclusions}

As I have pointed out in the introduction, the division of the research history of a subject into eras is itself a delicate area because the aspects taken into account in its process can always be questioned. At the same time, the main purpose of a chronological approach is to help orientation in time. In my view, there is no point in dividing a research history into periods consisting of long centuries and their achievements with the help of some transparent but rigid system (e.g. decades or centuries) since it does not provide any grip except for some cases (some of the objective ones) when it can become a tool for time orientation. I think it is more important for us to have such an overview. It can become arbitrarily subjective in some respects as it is used by researchers to make others see and understand what they want to say. So far, divisions in research history have served this purpose as they have used the retrospective of the past to value what was accomplished and to highlight the gaps that need to be filled in. If one wishes to write the history of the research history of Hungarian dialectology, one will inevitably consider some aspects irrelevant or less relevant that may be of great importance to a minority researcher.

The division into periods I have presented here set out to look primarily at the path of general Hungarian dialectology. Context and personalities involved in this highly marginalized topic are also important, and such are the roots and consequences of the long-standing delay when compared to other European countries. As such, there were aspects that I consider important milestones in the development of research on the subject such as the language reform, which drew scholarly attention to the vernacular, and the 1920 Trianon Peace Treaty, which by all means was a watershed in the context of Hungarian linguistics and in science in general. Similarly important was the publication of the journal Magyar Nyelvör, the establishment of the Magyar Nyelvtudományi Társaság, which represented a framework in which the institutional or scientific nature of the field of science changed greatly when discussing the "Romanian" aspects, important and prominent personalities being the decisive ones, who, through their work, induced considerable progress in the research of Hungarian dialects. 
It is a peculiar part of Hungarian dialectology that has become truly researchable only after the emergence and spread of the geolinguistic method, and it has occasionally appeared in the form of publications but has not really become the focus of interest. The reason for this was its place among the priorities, the lack of a specialist, and more recently the marginalization of dialectology as a field of research.

\section{References}

Bakó, Elemér. 1994. A magyar népnyelvkutatás sorsfordulói [Milestones of Hungarian dialectology]. Magyar Nyelv 90(2): 146-157.

Balassa, József. 1890. A székelyek nyelve. A székely-kérdés kritikájához [The language of the Seklers. Notes on the Sekler question]. Ethnographia 1(7): 309313.

1891. A magyar nyelvjárások osztályozása és jellemzése [Classification and description of Hungarian dialects]. Budapest: Magyar Tudományos Akadémia. 1898a. A magyar nyelvjárások keletkezése [Origins of Hungarian dialects]. Ethnographia 9(3): 185-196.

1898b. A magyar nyelvjárások keletkezése II. [Origins of Hungarian dialects II]. Ethongraphia 9(4): 282-293.

1898c. A magyar nyelvjárások keletkezése III. [Origins of Hungarian dialects III]. Ethnographia 9(5): 341-348.

Bárczi, Géza. 1995. A magyar nyelvjáráskutatás időszerú feladatai [Current tasks of the Hungarian dialectology]. Irodalomtudományi Osztály Közleményei 6(1-2): 59-115.

Benkő, Loránd. 1994. Erdély „nyelvünk vidám tavaszán” [Transylvania in the cheerful spring of our language]. In: Bartha, János et al. (eds.), Az Erdélyi Magyar Nyelvmúvelő Társaság kétszáz éve (1793-1993). Erdélyi Tudományos füzetek 218: 8-13.

Cs. Nagy, Lajos. 2007. Szóföldrajzi térképlapok a kolozsvári egyetem archívumában [Geolinguistic maps in the Archives of the University of Cluj]. Nyelv- és Irodalomtudományi Közlemények 51(1-2): 121-129.

Deme, László. 1953. A magyar nyelvjárások néhány kérdése [Questions related to the Hungarian dialects]. Budapest: Akadémiai Kiadó.

Erdélyi, Lajos. 1904. Nyelvjárásaink tanulmányozásához [To the study of our dialects]. In: Erdélyi, Lajos-Horger, Antal-Szemkő, Aladár, Nyelvjárási tanulmányok II. Nyelvészeti Füzetek 13. Budapest. 3-19.

1905a. Nyelvjárásaink ügye és teendőink I [The issue of our dialects and our tasks I]. Magyar Nyelv 1(7): 291-305.

1905b. Nyelvjárásaink ügye és teendőink II. [The issue of our dialects and our tasks II]. Magyar Nyelv 1(8): 337-349. 
Gáti, István. 1821. Elmélkedés a’ magyar dialectusról, lexiconról, és helyes írásról [Thinking about the Hungarian dialects, lexicon, and orthography]. In: Jutalom feleletek a’ magyar nyelvról, a’ Magyar Nemzetu Museum 1815, 1816, 1817. esztendei kérdéseire, vol II. Pest: István Horváth - A’ Széchényi Országos Könyvtár Őrzője a’ Magyar Nemzeti Museum mellett.

Geleji Katona, István. 1645. Magyar Gramatikatska [Little Hungarian grammar]. Republication by Simonyi Zsigmond. 1906. Nyelvészeti Füzetek 30.

Gombocz, Zoltán. 1927. Leíró nyelvtan, történeti nyelvtan [Descriptive grammar, historical grammar]. Magyar Nyelv 23(1-2): 1-6.

Horger, Antal. 1905. A keleti székelység nyelvjárási térképe [Geolinguistic map of the Eastern Seklers]. Magyar Nyelv 1(10): 446-454.

1934. A magyar nyelvjárások [The Hungarian dialects]. Budapest: Lajos Kókai.

Imre, Samu. 1971. A mai magyar nyelvjárások rendszere [The system of contemporary Hungarian dialects]. Budapest: Akadémiai Kiadó.

1978. Tudománytörténeti kérdések a magyar dialektológiában [Questions related to research history in the Hungarian dialectology]. Irodalomtudományi Osztály Közleményei 30(3): 139-153.

Kiss, Jenő. 2018. A magyar nyelvtörténet korszakolása és korszakai [Periodization and periods in the history of the Hungarian language]. In: Kiss, Jenő-Pusztai, Ferenc (eds.), A magyar nyelvtörténet kézikönyve. 43-47.

Márton, Gyula. 1973. A romániai magyar nyelvjáráskutatás múltja és mai állása [The past and present of Hungarian dialectology in Romania]. In: Ritoók, János (ed.), Korunk Évkönyv 1973. (Tanulmányok a romániai magyar tudományosság múhelyéből). Cluj-Napoca. 173-193.

Nagy, Géza. 1890. A székelyek és a pannóniai magyarok [The Seklers and the Hungarians from Pannonia]. Ethnographia 1(4): 165-179.

Nagy, Jenő. 1984. Az erdélyi szász eredet- és nyelvjáráskutatás története [History of research on Transylvanian Saxons' origin and dialect].

P. Gegő, Elek. 1838. A’ moldvai magyar telepekról [On the Hungarian colonies of Moldova]. Buda: Academia.

Palóczi Horváth, Ádám. 1821. A’ Magyar Nyelv’ Dialectusairól [On the dialects of the Hungarian language]. In: Jutalom feleletek a' magyar nyelvról, a’ Magyar Nemzeti Museum 1815, 1816, 1817. esztendei kérdéseire, vol I. Pest: István Horváth - A’ Széchényi Országos Könyvtár Őrzője a’ Magyar Nemzeti Museum mellett.

Pápay, József. 1896. Egy dunántúli nyelvjárás-sziget [A dialect island from Transdanubia]. Magyar Nyelvór 25: 207-210.

Réthy, László. 1890. A székelyek s a magyar honfoglalás [The Seklers and the Hungarian Conquest]. Ethnographia 1(1): 24-37.

Szabó, József. 1990. Magyarországi és jugoszláviai magyar nyelvjárásszigetek [Hungarian Dialect islands in Hungary and in Yugoslavia]. Dél-alföldi évszázadok 3. Békéscsaba-Kecskemét-Szeged. 
Szabó, Zoltán. 1993. A kolozsvári magyar dialektológiai iskola [The Hungarian dialectogy school in Cluj]. In: Békés, Imre et al. (eds.), Régi és új peregrináció. Magyarok külföldön, külföldiek Magyarországon. vol. III. Budapest-Szeged: Nemzetközi Filológai Társaság-Scriptum Kft. 1430-1432.

Tagányi, Károly. 1890. A honfoglalás és Erdély. Megvilágításul a székely kérdéshez [The Conquest and Transylvania. Shedding light on the Sekler issue]. Ethnographia 1(5): 213-223.

Vass, Béla. 1909. A nagykőrösi nyelvjárás [The dialect of Nagykőrös]. Nyelvészeti Füzetek 57. Budapest: Athenaeum Irodalmi és Nyomdai Rt.

Vass, József. 1860. Dunántúli Nyelvjárás [The Transdanubian dialect]. Magyar Nyelvészet 5: 63-163.

Viski, Károly. 1913. A szalontai nép nyelvéről [On the language of the people of Szalonta]. Nyelvészeti Füzetek 69. Budapest: offprint from Magyar Nyelvốr. 